\title{
NEUROCRYPTOCOCCOSIS: DIAGNOSIS BY PCR METHOD
}

\author{
Regina Célia PASCHOAl(1), Mário Hiroyuki HIRATA(1), Rosário Crespo HIRATA(1), Márcia de Souza Carvalho MELHEM(2),
} Amanda Latercia Tranches DIAS(3) \& Claudete Rodrigues PAULA(3)

\begin{abstract}
SUMMARY
Cryptococcus neoformans detection was optimized using PCR technique with the objective of application in the clinical laboratory diagnosis. The amplification area was ITS and 5,6S which encodes the ribosomal RNA (rRNA). A total of 72 cerebrospinal fluid (CSF) samples were used, obtained from cases with and without AIDS. The patients had cryptococcal meningitis ( $\mathrm{n}=56$ ) and meningitis caused by other agents $(\mathrm{n}=16)$. The results demonstrated that PCR test had the highest sensitivity rates, superior to culture $(85.7 \%)$ and to India ink test $(76.8 \%)$. PCR was found to be sensitive in detecting $1 \mathrm{cell} / \mathrm{mL}$ and highly specific since it did not amplify other fungal DNA. The comparative analysis of the methods showed that PCR is more sensitive and specific and is applicable as an important laboratorial resource for neurocryptococcosis diagnosis.
\end{abstract}

KEYWORDS: Cryptococcus neoformans; PCR; Diagnostic methods; AIDS; Cryptococcosis

\section{INTRODUCTION}

Cryptococcosis is a cosmopolitan infection caused by Cryptococcus neoformans, an encapsulated yeast pathogenic to humans and animals ${ }^{1,13,18}$

In the last decades, cryptococcosis has been assuming a prominent role at public health level due to the growing number of AIDS individual cases $^{2,3,20}$. It is an important opportunist systemic mycosis that involves mainly immunosuppressed individuals and starts when $C$. neoformans penetrates the organism, lodging primarily in the lungs and later presents a notable tropism for the central nervous system ${ }^{7,9,14}$. Molecular tests for detecting nucleic acids of infectious agents in biological samples have been developed for $C$. neoformans. These can be done in various clinical materials, such as blood, liquor, secretions, cutaneous scrapings, bronchial alveolar aspirate and urine ${ }^{24}$. For the diagnosis of neurocryptococcosis the application of more sensitive and specific laboratorial techniques are necessary in order to introduce early and specific antifungal therapy. PCR offers a good alternative ${ }^{11}$. It constitutes a method of choice for early alternative diagnosis to the conventional ones and contributes to supply important subsidies to the diagnosis of this pathology mainly when there is clinical suspicion of the disease ${ }^{12}$. The DNA of $C$. neoformans can be detected by initiators that encode the ribosomal RNA (rRNA) gene $16 \mathrm{~S}-5 \mathrm{~S}, 8 \mathrm{~S}-23 \mathrm{~S}$ which is highly conserved $^{4,17}$.

In this work the single-step PCR technique on clinical samples was optimized by utilizing the initiator pairs $\mathrm{CN}-4 / \mathrm{CN}-5$ that are specific for
C. neoformans and do not amplify the DNA of other yeast ${ }^{17}$. This technology involves yeast acid nucleic isolation, amplification by PCR and identification by electrophoresis on polyacrylamide gel with silver salt staining.

\section{MATERIALS AND METHODS}

1. Biological samples: The CSF samples were obtained from individuals with and without neurocryptococcosis signals. The collection was carried out through lumbar and occipital puncture. The material was dripped directly into sterile tubes and divided into three groups for later analysis:

Group 1: Constituted of 43 individuals with or without clinical suspicion of meningitis and laboratorial diagnosis of meningitis, independent of age, color or sex with positive culture for $C$. neoformans.

Group 2: Constituted of 13 individuals with clinical picture and laboratorial diagnosis of meningitis, independent of age, color or sex, with negative culture and positive China ink test for $C$. neoformans.

Group 3: Constituted of 16 individuals with or without clinical suspicion of meningitis caused by other agents not related to $C$. neoformans, independent of age, color or sex, with negative culture and India Ink Test for C. neoformans.

Other methodologies were evaluated for DNA extraction from $C$. neoformans in culture and in CSF samples: from simple extraction with

(1) University of São Paulo, USP, Faculty of Pharmaceutical Sciences, Department of Clinical Analyses and Toxicology, São Paulo, SP, Brazil.

(2) Adolfo Lutz Institute, São Paulo, SP, Brazil.

(3) Department of Microbiology, Institute of Biomedical Sciences, USP, São Paulo, SP, Brazil.

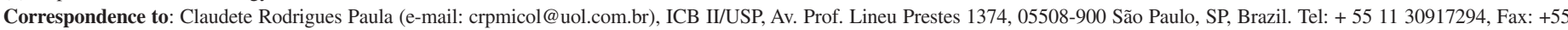
1130917354 
glass spheres ${ }^{10,19,28}$, extraction of DNA with sodium iodide ${ }^{15}$ and with guanidine thiocyanate ${ }^{24}$ to more complex methods involving enzymes $^{22,25,26,27,29}$.

2. DNA extraction: The SANDHU extraction technique ${ }^{24}$ was performed: $2 \mathrm{~mL}$ of clinical sample were placed in a sterile $15 \mathrm{~mL}$ polypropylene test tube and centrifuged at $5000 \mathrm{rpm}$ during five min. The sediment was transferred to another sterile $1.5 \mathrm{~mL}$ microtube. Then $500 \mu \mathrm{L}$ of the reagent GPT (6M guanidine thiocyanate) dissolved in $50 \mathrm{mM}$ TRIS ( $\mathrm{pH} 8.3$ ) was added after mixing with an equal volume of phenol TRIS ( $\mathrm{pH}$ 8.0). The resulting mixture was thoroughly stirred and immediately incubated by boiling water bath during $15 \mathrm{~min}$. Next, $250 \mu \mathrm{L}$ of chloroform: amyl alcohol (24:1 per volume) was added under vigorous stirring followed by centrifugation for five min at $12000 \mathrm{rpm}$. The aqueous phase was transferred to a new and sterile tube followed by addition of one $\mathrm{mL} 100 \%$ isopropanol. This set was freezer-stored for a minimum of one $\mathrm{h}$ and then centrifuged for $10 \mathrm{~min}$ at $12000 \mathrm{rpm}$. The supernatant was discharged. Next, $500 \mu \mathrm{L} 70 \%$ ethanol was added to the sediment. Centrifugation during five min at $12000 \mathrm{rpm}$ was performed and the sediment was resuspended in $50 \mu \mathrm{L}$ buffer TE (10 mM TRIS, 1 $\mathrm{mM}$ EDTA, $\mathrm{pH}$ 8.0) and freezer-stored at $-20{ }^{\circ} \mathrm{C}$ until use.

3. Primers: For the $C$. neoformans genome amplification we selected and tested primers "sense" CN-5 (3'GAA GGG CAT GCC TGT TTG AGA G 5') and "antisense" CN-4 ( 5'ATC ACC TTC CCA CTA ACA CAT T 3') as described by MITCHELL et al. ${ }^{16}$ which are specific for $C$. neoformans.

4. PCR method: After the extraction, $5 \mu \mathrm{L}$ DNA of each sample were added to the $200 \mu \mathrm{L}$ Eppendorf type tubes. Next, buffer solution for PCR was pipetted [75 mM TRIS- $\mathrm{HCl}$ ( $\mathrm{pH} 9.0$ ), $50 \mathrm{mM} \mathrm{KCl,} 2 \mathrm{mM} \mathrm{MgCl}$, BIOTOOLS - B\&M Labs, S.A]; $200 \mathrm{mM}$ of each dNTP (dATP, dTTP, dGTP and dCTP, Pharmacia Biotech), 1.5 U/ $\mu \mathrm{L}$ Taq DNA polymerase (BIOTOOLS - B\&M Labs, S.A.); $10 \mathrm{\rho mol} / \mu \mathrm{l}$ of each primer (Gibco-BRL Life Technologies NY-USES) for a reaction final volume of $50 \mu \mathrm{L}$. The amplification was realized in thermocycle GeneAmp 2400 (Perkin-Elmer, USA) and consisted of one cycle at $95^{\circ} \mathrm{C}$ for $7 \mathrm{~min}$ (hot start), 40 cycles at $95^{\circ} \mathrm{C}$ for $45 \mathrm{sec}$ (denaturation), $60^{\circ} \mathrm{C}$ for one min. (annealing), $72{ }^{\circ} \mathrm{C}$ for $1.5 \mathrm{~min}$ (extension) and $72{ }^{\circ} \mathrm{C}$ for $7 \mathrm{~min}$ (final extension).

4.1. Analysis of the PCR products: The electrophoresis separation was accomplished on $8 \%$ polyacrylamide gel with $20 \mu \mathrm{L}$ of the PCR product containing $10 \mu \mathrm{L}$ of run buffer (6X concentrated). The system was submitted to 95 Volts during $6 \mathrm{~h}$ and later silver-stained through impregnation technique to permit observation of the DNA dark brown color bands (Fig. 1)

4.2. Specificity of the primers: The chosen primers $\mathrm{CN}-4$ and $\mathrm{CN}-$ 5 presented high specificity for $C$. neoformans serotypes A, B, C and D cultures for CSF samples where the yeast was present. The primer did not amplify other types of yeasts such as: Candida albicans ATCC 64548, Candida parapsilosis ATCC 22019, Candida tropicalis ATCC 750, Candida glabrata ATCC 90030, Cryptococcus luteolus ICB, Cryptococcus terreus ICB, Cryptococcus diffluens ICB 72 and Rhodotorula glutinis ICB 32 (Fig. 2).

4.3. Sensitivity of the PCR method: The technique was sensitive for the detection of up to 1 cell/ $\mathrm{mL}$ in CSF samples. The PCR amplification yielded a DNA fragment of $136 \mathrm{bp}$ in all concentrations (Fig. 3). Each reaction was accompanied with control reagents and positive control with 6,000 cells/mL (data not showed).

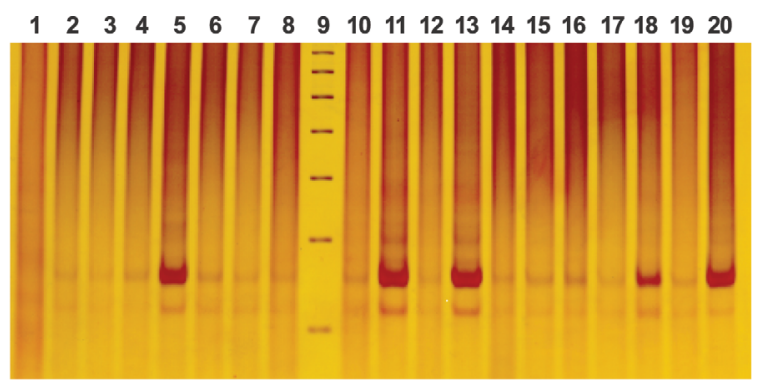

Fig. 1 - Electrophoretic separation on $8 \%$ polyacrylamide gel of the PCR products from $C$. neoformans in CSF sample extracted with guanidine thiocyanate. Line 1 reagent control; line 5 positive control; lines 2, 3, 4, 6-8, 10-20 samples of CSF; line 9: DNA ladder 100bp (standard);

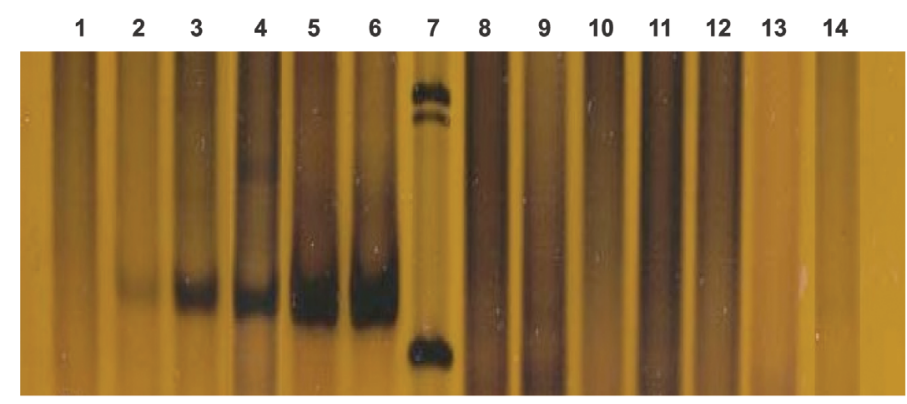

Fig. 2 - PCR Sensitivity. Line 1: reagent control; line 2: positive control; line 3,4,5 and 6: $C$. neoformans serotype A, B, C and D; line 7: DNA ladder 123 bp; lines 8, 9 and 10 Cryptococcus terreus, Cryptococcus diffluens and Cryptococcus luteolus; line 11: Rhodotorula glutinis, lines 12, 13 and 14: Candida albicans, Candida tropicalis and Candida glabrata.

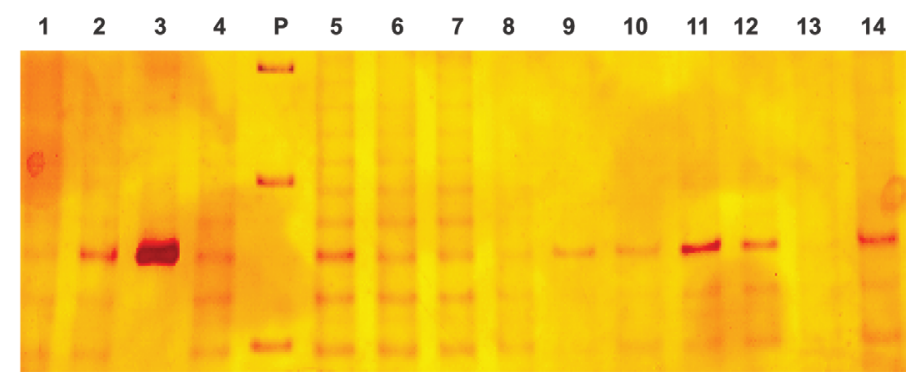

Fig. 3 - Electrophoresis on 8\% polyacrylamide gel from clinical sample PCR product with different amounts of cells. Lines 1: 2 cells; 2 : 11 cells; 3: positive control; 4: 70 cells; P: 100bp molecular weight DNA pattern; 5: 40 cells; 6: zero cell; 7: 1 cell; 8: zero cell; 9: 58 cells; 10: 1 cell; 11 : 14 cells; 12 : 65 cells; $13: 28$ cells; 14 : 110 cells.

\section{RESULTS}

In Table 1, the results obtained by culture, India Ink Test and PCR techniques were compared in the study of 72 CRL samples (groups 1, 2 and 3). It was found that all the techniques were $100 \%$ specific (75.9 $100 \%$ ) and that PCR technique amplifies only C. neoformans specie DNA $^{11,16}$. 


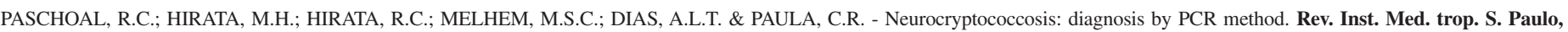
46(4):203-207, 2004

Table 1

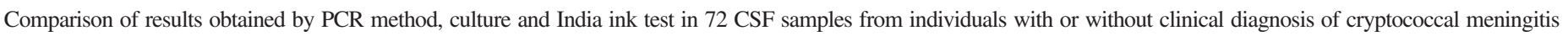

\begin{tabular}{|c|c|c|c|c|c|c|c|c|c|}
\hline $\begin{array}{l}\text { Samples } \\
\mathrm{n}=72\end{array}$ & & $\begin{array}{c}\text { Cryptococcal } \\
\text { meningitis } \\
n=56\end{array}$ & $\begin{array}{c}\text { Other } \\
\text { meningites } \\
\mathrm{n}=16\end{array}$ & $\begin{array}{c}\text { Sensitivity } \\
(\%)\end{array}$ & $\begin{array}{c}\text { Specificity } \\
(\%)\end{array}$ & $\begin{array}{l}\text { PPV } \\
(\%)\end{array}$ & $\begin{array}{l}\text { NPV } \\
(\%)\end{array}$ & $\begin{array}{l}\text { FP } \\
(\%)\end{array}$ & $\begin{array}{l}\mathrm{FN} \\
(\%)\end{array}$ \\
\hline Culture & $\begin{array}{l}\text { Pos } \\
\text { Neg }\end{array}$ & $\begin{array}{l}43 \\
13\end{array}$ & $\begin{array}{c}0 \\
16\end{array}$ & $\begin{array}{c}76.8 \\
(63.3-86.6)\end{array}$ & $\begin{array}{c}100 \\
(75.9-100)\end{array}$ & $\begin{array}{c}100 \\
(89.8-100)\end{array}$ & $\begin{array}{c}55.2 \\
(36.0-73.0)\end{array}$ & 0 & 0 \\
\hline China Ink Test & $\begin{array}{l}\text { Pos } \\
\text { Neg }\end{array}$ & $\begin{array}{c}48 \\
8\end{array}$ & $\begin{array}{c}0 \\
16\end{array}$ & $\begin{array}{c}85.7 \\
(73.2-93.2)\end{array}$ & $\begin{array}{c}100 \\
(75.9-100)\end{array}$ & $\begin{array}{c}100 \\
(90.8-100)\end{array}$ & $\begin{array}{c}66.7 \\
(44.7-83.6)\end{array}$ & 0 & 33.3 \\
\hline PCR & $\begin{array}{l}\mathrm{Pos} \\
\mathrm{Neg}\end{array}$ & $\begin{array}{c}52 \\
4\end{array}$ & $\begin{array}{c}0 \\
16\end{array}$ & $\begin{array}{c}92.9 \\
(81.9-97.7)\end{array}$ & $\begin{array}{c}100 \\
(75.9-100)\end{array}$ & $\begin{array}{c}100 \\
(91.4-100)\end{array}$ & $\begin{array}{c}80.0 \\
(55.7-93.4)\end{array}$ & 0 & 20.0 \\
\hline
\end{tabular}

Pos = positive $;$ Neg = negative PPV = positive predictive value NPV = negative predictive value $; \mathrm{FP}=$ false positive $;$ FN = false negative

The PCR method presented the greatest sensitivity with $92.9 \%$ (81.9 - $97.7 \%)$. The specificity was $100 \%$ (75.9 - 100\%), with positive predictive value $100 \%$ (91.4 - 100\%), there were no false positives; negative predictive value was $80.0 \%$ (55.7 - 93.4\%) with $20 \%$ false negatives which refer to four samples of group 2 that presented positive India Ink Test. The India Ink Test sensitivity $85.7 \%(73.2-93.2)$, specificity $100 \%(75.9-100 \%)$, positive predictive value $100 \%$ (90.8 - 100\%) and negative predictive value $66.7 \%(44.7-83.6 \%)$ generating a false negative of $33.3 \%$, due to 8 samples of group one that presented positive culture but negative values with India Ink test. Nevertheless, the culture that was considered the gold standard of this study presented sensitivity $76.8 \%$ (63.3 - 86.6\%), specificity $100 \%$ (75.9 - 100\%), positive predictive value $100 \%(89.9-100 \%)$ and negative predictive value $55.2 \%$ (36.0 - 73.0\%), generating false negatives of $44.8 \%$ due to 13 samples of group 2 that presented positive value with India ink test but negative culture.

\section{DISCUSSION}

In the present study, we optimized the method for the detection of C. neoformans by PCR technique in CSF samples with the objective of developing a new diagnosis resource that, associated with methods already used in laboratorial routine, can increase the diagnostic efficiency in cases where conventional techniques are inadequate ${ }^{11}$.

At the standardization phase of DNA extraction method, the extraction efficiency, speed, simplicity of manipulation, ease of obtaining the material and low cost were taken into account; since these requirements are indispensable in order to ensure the method is applicable for routine laboratorial use. From simple DNA extraction with glass beads ${ }^{10,19,28}$, DNA extraction with sodium iodine methods ${ }^{16}$ and with guanidine thiocyanate ${ }^{24}$ to more complex methods involving enzymes $^{21,22,25,26,27,29,30}$ all them were efficient for the extraction of DNA from cultures of $C$. neoformans. The extraction with guanidine thiocyanate is fast, presents easy execution, low cost and is much more efficient for CSF sample extraction than $C$. neoformans culture. This was demonstrated to be the only efficient technique for $C$. neoformans DNA extraction from clinical samples, working even with small amounts of yeast.

In order to evaluate the specificity of the primers, DNA of several ATCC and ICB yeast strains were tested and none of their DNA was amplified. Strains for the four serotypes of C. neoformans were also utilized as a standard. The validity of the methodology was studied through the evaluation of efficiency in the case of material obtained at the medical clinic. For that, CSF materials were studied as samples and were subdivided into three study groups:

Group 1, constituted of individuals with clinical diagnosis of neurocryptococcosis, with positive results for culture and India Ink test, PCR demonstrated high sensitivity (100\%) and specificity (100\%) without any false negatives; Group 2, constituted of neurocryptococcosis cases, with positive value to India Ink test and negative culture, PCR proved to be sensitive (69.2\%) and specific (100\%). In four individuals (30.8\%) that presented negative PCR, two of the corresponding sample cells were not found; in the other two there were three and 46 cells, respectively. This was probably due to the capsule being thicker in clinical samples compared to those of cultures. Thus, the high thickness of the capsules may have considerably hindered the cellular lysis. Another hypothesis for this finding could be interferents in CSF, which may have inhibited the PCR. It is supposed that these interferents may be related to the great amount of antibiotics, anti-retroviral agents, proteases and other drugs administered to the AIDS patient, which may not have been eliminated at the DNA extraction. Occasionally, the presence of great capsular polysaccharide amounts can alter the activity of Taq polymerase and compromise the accuracy of $\mathrm{PCR}^{5}$. In group 3, constituted of individuals with other neurological diseases not related to C. neoformans, PCR was demonstrated to be specific (100\%) and did not present fragment amplification in any of the samples and there were no false positive results.

Comparison of the three groups showed a predominance of 58 male individuals $(80.6 \%)$ with a mean age between 36 to 39 years and a less expressive number of 14 female individuals (19.4\%) with a mean age from 23 to 36 years.

PCR presented a higher sensitivity in relation to India ink test and culture due to the following factors that interfere in the $C$. neoformans growth and visualization: a) for the India ink test be positive it is necessary that there are more than $103 \mathrm{CFU} / \mathrm{mL}$; b) C. neoformans shows different forms and sizes in CSF and sometimes does not present capsules, impeding its visualization; c) the culture medium composition has to offer some source of iron; d) some aberrant strains of $C$. neoformans are unable to grow in BHI (brain and heart infusion) medium, but grow well 
on SDA (Sabouraud's dextrose agar); e) the growth can be significantly inhibited at temperatures between $39-40{ }^{\circ} \mathrm{C}$; f) some patients that received antifungal therapy can present negative culture, but positive result to India ink test at the end of therapy, irrespective of clinical improvement; and g) $\mathrm{pH}$ above 7.6 causes the death of the yeast ${ }^{5}$.

India ink test presented $85.7 \%(73.2$ - 93.2\%) sensitivity; positive predictive value of $100 \%(90.8-100 \%)$ and did not present false negatives, but a negative predictive value of $66.7 \%(44.7-83.6 \%)$ in that $33.3 \%$ false negatives were found, amounting to eight samples from group one that were negative and under direct microscopy presented an absence of cells that probably harmed the color exam.

In relation to culture evaluation, a sensitivity of $76.8 \%(63.3-86.6 \%)$ was found due to 13 negative samples from group two. Of these, five samples were negative under direct microscopy, five samples presented low cellularity $(3,3,28,30$ and 46 cells) and three high cellularity (110, 148 and 1080 cells). This can occur when antifungal therapy has already been initiated, thereby inhibiting cellular growth and negativation of the culture, but the presence of the yeast is detected by the India ink test and therefore in some cases is positive until the end of the therapy, irrespective of clinical improvement. It has yet to be clarified why these nonviable yeasts occasionally persist for months after the antifungal therapy ${ }^{5}$.

RAPPELLI et al. $^{23}$ utilized the same protocol of DNA extraction of SANDHU et al. ${ }^{24}$ and realized the identification of $C$. neoformans by "nested" PCR technique and observation of the DNA fragments on agarose gel stained with ethidium bromide. The demonstrated results, in accordance with SANDHU et al. ${ }^{24}$ were significantly better for the following data:

In the protocol of RAPPELLI et al. ${ }^{23}$ all CSF samples used had at least one cell per field in India ink test and presented latex agglutination titer 1:1024, data strongly indicative of neurocryptococcosis .

Some authors detected DNA from samples that did not present culture and India ink test, positive. These authors used "nested" PCR to increase the DNA detection sensitivity. This method is both time consuming and expensive besides the major inconvenience that there is a risk of causing contamination $^{6,8}$.

The primer pairs used in the "nested" PCR also amplify the saprophytic Filobasidiella depauperata and so can give a false positive result. The primers $\mathrm{CN}-4$ and $\mathrm{CN}-5$ used in this study do not amplify yeast other than $C$. neoformans because they are species-specific ${ }^{17}$.

Hence, the strategy developed in this study allowed a reduction in the time for $C$. neoformans detection and identification since it entails just a single step for the amplification, which avoids contamination and offers satisfactory results with the same sensitivity as the method proposed by RAPPELLI et al. ${ }^{23}$.

The results show that DNA extraction with guanidine thiocyanate was the only efficient method for $C$. neoformans DNA extraction in CSF samples, besides being fast and easy to perform. The PCR method has proven to be efficient in detecting up to one cell/mL in CRL samples, even in cases where antifungal therapy has been initiated. In the overall evaluation of the studied groups, this technique showed sensitivity of
$92.9 \%$ and specificity of $100 \%$. It can be used for the diagnosis of neurocryptococcosis, therefore its use is viable in the laboratorial routine.

The PCR method is sensitive, specific, and reproducible and represents a promising method for analysis of CSF samples from patients with clinical suspicion of neurocryptococcosis.

\section{RESUMO}

\section{Neurocriptococose: diagnóstico por PCR}

A detecção de Cryptococcus neoformans em líquor foi otimizada pela técnica de PCR. A amplificação foi realizada nas áreas ITS e 5,6S do RNA ribossomal (rRNA). Foram estudados 72 líquors obtidos de casos de pacientes com e sem AIDS. Os pacientes eram portadores de meningite criptocócica $(n=56)$ e meningite ocasionada por outros agentes $(n=16)$. Os resultados demonstraram que a técnica tem alta sensibilidade, superior a cultura $(85,7 \%)$ e ao teste da tinta da china $(76,8 \%)$. A técnica de PCR pode detectar 1 célula/mL de líquor e é altamente específica. A análise comparativa dos três métodos, tinta da china, cultura e PCR, demonstrou que o último é muito mais sensível e específico, podendo ser aplicável como importante recurso laboratorial no diagnóstico da neurocriptococose.

\section{ACKNOWLEDGMENTS}

We thank Professor Carlos da Silva Lacaz (in memoriam) for suggestions, the Bacteriology Section at Emílio Ribas Infectology Institute that supplied the CSF samples and FAPESP for financial support.

\section{REFERENCES}

1. BARONI, F.A. - Ocorrência de Cryptococcus neoformans em excretas de pombos localizados em torres de igrejas na cidade do Rio de Janeiro: fatores de virulência e sensibilidade aos antifúngicos. São Paulo, 2001. (Tese de Doutorado - Instituto de Ciências Biomédicas da Universidade de São Paulo).

2. BARRETO DE OLIVEIRA, M.T.; BOEKHOUT, T.; THEELEN, B. et al. - Cryptococcus neoformans shows a remarkable genotypic diversity in Brazil. J. clin. Microbiol., 42: 1356-1359, 2004.

3. BIALEK, R.; WEISS, M.; BEKURE-NEMARIAM, K. et al. - Detection of Cryptococcus neoformans DNA in Tissue Samples by Nested and Real-Time PCR Assays. Clin Diag. Lab. Immunol., 9: 461-469, 2002.

4. BROUWER, A.E.; RAJANUWONG, A.; CHIERAKUL, W. et al. - Combination antifungal therapies for HIV-associated cryptococcal meningitis: a randomised trial. Lancet, 363: 1764-1767, 2004.

5. CASADEVALL, A. \& PERFECT, J.R. - Cryptococcus neoformans. Washington, American Society for Microbiology, 1998.

6. DIAMOND, R.D. \& BENNETT, J.E. - Prognostic factors in cryptococcal meningitis. Ann. intern. Med., 80: 176-181, 1974.

7. D'SOUZA, C.A.; HAGEN, F., BOEKHOUT, T.; COX, G.M. \& HEITMAN, J. Investigation of the basis of virulence in serotype A strains of Cryptococcus neoformans from apparently immunocompetent individuals. Curr. Genet., 46: 92-102, 2004.

8. ERLICH, H.A.; HIGUCHI, R.; LICHTENWALTER, K.; REYNOLDS, R. \& SENSABAUGH, G. - Reliability of the HLA-DQ alpha PCR-based oligonucleotide typing system. J. forens. Sci., 35: 1017-1019, 1990. 

46(4):203-207, 2004.

9. FERNANDES, O.F.L.; COSTA, T.R.; COSTA, M.R. et al. - Cryptococcus neoformans isolados de pacientes com AIDS. Rev. Soc. bras. Med. trop., 33: 75-78, 2000

10. HAYNES, K.A.; WESTERNENG, T.J.; FELL, J.W. \& MOENS, W. - Rapid detection and identification of pathogenic fungi by polymerase chain reaction amplification of large subunit ribosomal DNA. J. med. vet. Mycol., 33: 319-325, 1995.

11. IMWIDTHAYA, P. \& POUNGVARIN, N. - Cryptococcosis in AIDS. Postgrad. Med. J., 76: 85-88, 2000.

12. IYER, R.S. \& BANKER, D.D. - Cryptococcal meningitis in AIDS. Indian J. med. Sci., 56: 593-597, 2002

13. KWON-CHUNG, K.J. - Cryptococcosis. In: KWON-CHUNG, K.J. \& BENNETT, J.E., ed. Medical mycology. Philadelphia, Lea \& Febiger, 1992. p. 397-466.

14. LACAZ, C.S.; PORTO, E.; MARTINS, J.E.C.; HEINS-VACCARI, E.M. \& MELO, N. T. - Tratado de Micologia médica. São Paulo, Sarvier, 2002.

15. LOPAREV, V.N.; CARTAS, M.A.; MONKEN, C.E.; VELPANDI, A. \& SRINIVASAN, A. -An efficient and simple method of DNA extraction from whole blood and cell lines to identify infectious agents. J. virol. Meth., 34: 105-112, 1991.

16. MITCHELL, T.G.; FREEDMAN, E.Z.; MEYER, W.; WHITE, T.J. \& TAYLOR J.W. PCR identification of Cryptococcus neoformans. In: PERSING, D.H. et al., ed. Diagnostic molecular Microbiology: principles and applications. Washington, American Society for Microbiology, 1993. p. 431-436.

17. MITCHELL, T.G.; FREEDMAN, E.Z.; WHITE, T.J. \& TAYLOR, J.W. - Unique oligonucleotide primers in PCR for identification of Cryptococcus neoformans. J. clin. Microbiol., 32: 253-255, 1994.

18. MONTENEGRO, H. \& PAULA, C.R. - Environmental isolation of Cryptococcus neoformans var. gattii and Cryptococcus neoformans var. neoformans in the city of São Paulo, Brazil. Med. Mycol., 38: 385-390, 2000.

19. MURRAY, M.G. \& THOMPSON, W.F. - Rapid isolation of high molecular weight plant DNA. Nucleic Acids Res., 8: 4321-4325, 1980

20. PAPPALARDO, M.C.S.N. \& MELHEM, M.S.C. - Cryptococcosis: a review of the Brazilian experience for the disease. Rev. Inst. Med. trop. S. Paulo., 45: 299-305, 2003
21. PERFECT, J.R.; MAGEE, B.B. \& MAGEE, P.T. - Separation of chromosomes of Cryptococcus neoformans by pulsed field gel electrophoresis. Infect. Immun., 57: 2624-2627, 1989.

22. PRARIYACHATIGUL, C.; CHAIPRASERT, A.; MEEVOOTISOM, V. \& PATTANAKITSAKUL, S. - Assessment of the PCR technique goes the detection and identification of Cryptococcus neoformans. J. med. vet. Mycol., 34: 251-258, 1996.

23. RAPPELLI, P.; ARE, R.; CASU, G. et al. - Development of a nested PCR for detection of Cryptococcus neoformans in cerebrospinal fluid. J. clin. Microbiol., 36: 34383440, 1998.

24. SANDHU, G.S.; KLINE, B.C.; STOCKMAN, L. \& ROBERTS, G.D. - Molecular probes diagnosis of fungal infections. J. clin. Microbiol., 33: 2913-2919, 1995.

25. SCHERER, S. \& STEVEN, D.A. - Application of DNA typing methods to epidemiology and taxonomy of Candida species. J. clin. Microbiol., 4: 675-679, 1987.

26. SPITZER, E.D. \& SPITZER, S.G. - Uses of a dispersed repetitive DNA element to distinguish clinical isolates of Cryptococcus neoformans. J. clin. Microbiol., 30: 1094-1097, 1992.

27. TANAKA, K.; MIYAZAKI, T.; MAESAKI, S. et al. - Detection of Cryptococcus neoformans gene in patients with pulmonary cryptococcosis. J. clin. Microbiol. 34: 2826-2828, 1996

28. VAN BURIK, J.A.; SCHRECKHISE, R.W.; WHITE, T.C.; BOWDEN, R.A. \& MYERSON, D. - Comparison of six extraction techniques for isolation of DNA from filamentous fungi. Med. Mycol., 36: 299-303, 1998.

29. VARMA, A. \& KWON-CHUNG, K.J. - Rapid method to extract DNA from Cryptococcus neoformans. J. clin. Microbiol., 29: 810-812, 1991.

30. WALSH, T.J.; FRANCESCONI, A.; KASAI, M. \& CHANOCK, S.J. - PCR single-strand conformational polymorphism for recognition of medically important opportunistic fungi. J. clin. Microbiol., 33: 3216-3220, 1995.

Received: 8 July 2004

Accepted: 27 July 2004 